J. Clin. Chem. Clin. Biochem.

Vol. 19, 1981, pp. $1081-1083$

\title{
Role of the Thiazolyl Sulphur of Ambilhar as an Electron Donor in Metal Chelation
}

\author{
By F. T. Abdel Aziz, T. M. N. Al-Khayat, N. N. Izzat and N. Al-Jabour
}

Departments of Biochemistry and Physiology, Medical College, Mosul University, Mosul, Iraq

(Received April 11/October 20, 1980)

Summary: Administration of ambilhar or its $\mathrm{N}$-acetyl derivative to rabbits resulted in a significant increase in urinary iron excretion, due to chelation. Substitution of the sulphur of thiazole by nitrogen abolished its metal chelating power.

In vitro three different iron chelates were obtained, containing one or two iron atoms per mole of drug. However, in vivo studies revealed the presence of an ambilhar iron complex in which 6 molecules of the drug were chelated with one iron atom. Reduction is an important factor in the process of metal chelation by the thiazole sulphur of the drug.

\section{Rolle des Thiazolyl-Schwefels von Ambilhar als Elektronendonator bei der Metall-Chelat-Bildung}

Zusammenfassung: Applikation von Ambilhar oder seines N-Acetylderivats bei Kaninchen führte zu einem signifikanten Anstieg der Ausscheidung von Eisen im Harn aufgrund von Chelatbildung. Substitution des Thiazolyl-Schwefels durch Stịckstoff verstärkte die Chelatbildung. In vitro wurden drei verschiedene Eisenchelate, die ein oder zwei Atome Eisen enthielten, gefunden. In vivo wurde jedoch die Anwesenheit eines Chelats beobachtet, wobei sechs Moleküle ein Atom Eisen gebunden enthielten. Reduktion ist ein wichtiger Faktor im Prozeß der Metall-Chelat-Bildung durch Thiazolyl-Schwefel von Ambilhar.

\section{İntroduction}

Ambilhar, niridazole or nitrothiazole is a selective drug for schistosomiasis (1). Administration of the drug to normal rats caused a significant decrease in the iron content of liver and serum, with an accompanying increase in urinary iron excretion $(2,3)$, which was explained on the basis of metal chelation by the drug (4). Later on it was reported that ambilhar depleted calcium and magnesium in blood and tissues as a result of chelation (5). The same authors also demonstrated chelation by the drug in vitro.

Further studies on the active chelating centre in the drug molecule were not performed. Furthermore, little or no work on the factors affecting the chelating power of the drug with cations has been reported. It could therefore be of clinical rather than toxicological value to study the effect of some ambilhar derivatives on metal chelation in vivo as well as in vitro.

\section{Materials and Methods}

24 normal rabbits (Lepus caniculus), average body weight $1.5 \mathrm{~kg}$, were used. The animals were divided into four equal groups. Their diet consisted of normal greens (alfa alfa) growing in the area of Ninava in North of Iraq. Animals of groups 1,2 and 3 were dosed with ambilhar, acetyl ambilhar and a sulphur substituted derivative respectively. Those of group 4 were used as control.

Ambilhar (Analar grade) was obtained from Ciba-Geigy research Laboratories. The $\mathrm{N}$-acetyl derivative was prepared in our laboratories by treating a known weight of the drug with acetic anhydride for 24 hours. After crystallisation from hot water yellowish white crystals of m.p. $175^{\circ} \mathrm{C}$ were obtained.

The nitrogen-substituted derivative was prepared by mixing two $\mathrm{g}$ ambilhar, $3 \mathrm{~g}$ ammonium acetate and $20 \mathrm{ml}$ glacial acetic acid. The whole mixture was refluxed for 6 hours. The compound went into a dark brown solution and $\mathrm{H}_{2} \mathrm{~S}$ gas was evolved. The mixture was filtered and allowed to cool, and a brown crystalline compound was precipitated. This was crystallised from methanol to give yellow crystals of m.p. $240^{\circ} \mathrm{C}$ (dec.).

\section{Urinary iron estimation}

Total urine of each group of animals was collected daily and separately. The iron content of each group was quantitated after ashing $25 \mathrm{ml}$ of urine, and dissolving the ash in $5 \mathrm{ml}$ of $5 \mathrm{~mol} / 1$ $\mathrm{HCl}$, according to the method described by Ramsay (6).

\section{Iron ambilhar chelates in vitro}

To one gram pure crystalline ambilhar, two grams sodium metabisulphite and $100 \mathrm{mg}$ reduced iron metal (British Drug Houses) were added. The whole mixture was pulverised in a glass mortar, and added slowly to $50 \mathrm{ml}$ distilled water in a beaker. The mixture was boiled for a few minutes on a gentle direct flame, until it became a dark brown clear solution. After filtration and slow cooling, a dark crystalline compound was precipitated (complex 
1), which was recrystallized from glacial acetic acid. This compound was decomposed by heat, leaving a metallic residue. The filtrate was concentrated on a boiling water bath to half its volume, and left to cool gradually; a brown coloured substance (complex 2) separated. This was filtered, washed with $700 \mathrm{~g} / 1$ alcohol and distilled water, then crystallised from hot glacial acetic acid. It was decomposed by heat leaving a metallic residue. The filtrate was concentrated to one half its volume and left to cool, whereupon a brownish yellow compound (complex 3 ) separated. This was filtered, washed with alcohol and distilled water, then crystallised from glacial acetic acid. It was decomposed by heat leaving a metallic residue. The purity of the prepared complexes was tested by paper chromatographic studies using Whatman No. 1 filter paper; and $n$-butanol, glacial acetic acid and water $(20 \mathrm{ml}+20 \mathrm{ml}+10 \mathrm{ml})$ respectively in an ascending system. All the three iron complexes ran as single spots. Fifty mg samples of each complex were sent for microanalysis to Alfred Bernhardt (W. Germany).

\section{Ultra violet spectra of drugs and their iron complexes}

Ultra violet spectra of ambilhar, its nitrogen-substituted derivative and the laboratory-synthesized iron drug complexes 1, 2 and 3 were recorded with the aid of a Sp. 1800 spectrophotometer.

Microanalysis of the prepared nitrogen-substituted derivative ${ }^{1}$ )

$\begin{array}{llcl} & \begin{array}{l}\text { Analysis } \\ \text { Found }\end{array} & \text { Calculated } & \\ & & & \\ \text { Carbon } & 36.65 & 36.35 & \mathrm{C}_{6} \mathrm{H}_{7} \mathrm{~N}_{5} \mathrm{O}_{3} \\ \text { Hydrogen } & 3.46 & 3.55 & \\ \text { Nitrogen } & 35.81 & 35.53 & \end{array}$

Spectra: Infra red (Nujol) $\quad 3200-3250 \mathrm{~cm}^{-1}(\mathrm{NH})$

$$
1685 \mathrm{~cm}^{-1}(\mathrm{CO})
$$

NMR study: $\delta\left(C_{5} D_{5} N\right): 8.4$ (s, olefinic hydrogen) 9.07 (s, exchangable, $\mathrm{NH}$ of imidazole) 8.53 (s, exchangable NH of imidazolidinone)

$3.4-3.75,4-4.3\left(\mathrm{~m}, \mathrm{CH}_{2} \mathrm{CH}_{2}\right)$.

\section{Results}

Table 1 shows the effect of ambilhar, $\mathrm{N}$-acetyl-ambilhar and its nitrogen-substituted derivative on urinary iron output. Ambilhar and its $\mathrm{N}$-acetyl derivative caused a significant increase in the excretion of iron, whereas the nitrogen-substituted derivative showed little effect on urinary iron output.

Table 2 shows the iron percentage as well as the chelation ratios between the drug and iron in vitro. The percentage of iron in the complexes $(1,2,3)$ were found to be $44.2 \%, 22.27 \%$ and $10.07 \%$ respectively. This represents the chelation ratios of one mole of the drug with two iron atoms (complex 1), one mole of drug with one iron atom (complex 2) and two moles of the drug with one iron atom (complex 3 ) respectively.

Figure 1 demonstrates the effect of sodium metabisulphite on the spectrum of ambilhar. In the presence of this reducing agent, the major peak at $375 \mathrm{~nm}$ disappeared, while another peak at $240 \mathrm{~nm}$ appeared. After adding iron, the peak at $240 \mathrm{~nm}$ largely disappeared.

1) The preparation of this compound was a modification of the method reported by El-Kholy et al. (7), in which oxygen was replaced by nitrogen inside the heterocyclic ring.
Tab. 1. Effect of ambilhar, N-acetyl-ambilhar and its nitrogensubstituted derivative on urinary iron output in rabbits. (mg iron/day).

\begin{tabular}{lccc}
\hline Drug & \multicolumn{2}{l}{ Iron excretion } \\
& \multicolumn{2}{c}{$(\mathrm{mg} / \mathrm{d}) \overline{\mathrm{x}} \pm \mathrm{SD}$} & \\
& first day & second day & third day \\
\hline Ambilhar & 4.1 & 3.8 & 3.5 \\
& \pm 0.2 & \pm 0.3 & \pm 0.4 \\
N-acetyl-ambilhar & 4.5 & 3.5 & 3.35 \\
& \pm 0.18 & \pm 0.15 & \pm 0.12 \\
Nitrogen-substituted & $\left.0.18^{2}\right)$ & $\left.0.2^{2}\right)$ & $\left.0.15^{2}\right)$ \\
ambilhar $^{1}$ ) & \pm 0.01 & \pm 0.01 & \pm 0.01 \\
Control & 0.12 & 0.17 & 0.18 \\
& \pm 0.01 & \pm 0.01 & \pm 0.01 \\
\hline
\end{tabular}

1) 1(5-nitro-2 aminoimidazolyl)2-imidazolidinone

2) Significant at $1 \%$ level of probability

Tab. 2. Iron content (\%) of the in vitro prepared iron ambilhar complexes. (Alfred Bernhardt laboratories).

\begin{tabular}{llll}
\hline Chelate no. & $\begin{array}{l}\text { Iron } \\
(\%)\end{array}$ & $\begin{array}{l}\text { Chelation ratio } \\
\text { Ambilhar } \\
\text { molecule(s) }\end{array}$ & $\begin{array}{l}\text { Iron } \\
\text { atom(s) }\end{array}$ \\
\hline 1 & 44.2 & 1 & 2 \\
2 & 22.27 & 1 & 1 \\
3 & 10.07 & 2 & 1 \\
\hline
\end{tabular}

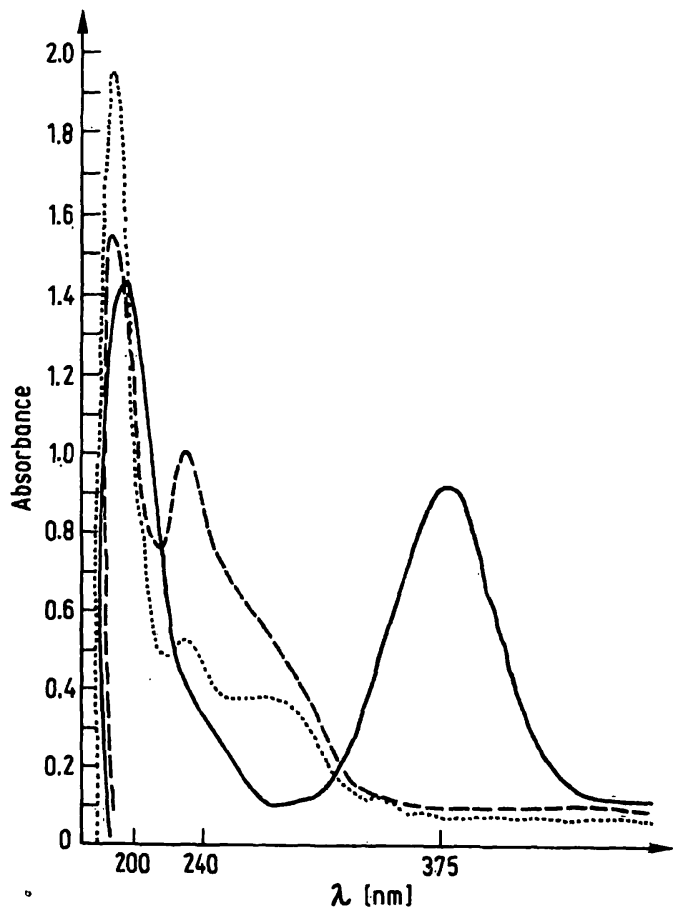

Fig. 1. Effect of reducing agents as well as iron chelation on the ultra violet spectrum of ambilhar (-). In the presence of sodium metabisulphite (-- ), the peak at $375 \mathrm{~nm}$ disappeared, while a new peak at $240 \mathrm{~nm}$ appeared. After subsequent chelation with iron $(\cdot \cdots \cdot . \cdot)$ disappearance of these two peaks was observed. 
Behaviour of the thiazole peak at $375 \mathrm{~nm}$ in metal chelation is also shown. Disappearance of this peak was also observed on reduction.

Figure 2 shows the ultra violet spectra of ambilhar and its nitrogen analogue. Disappearance of the major peak at $375 \mathrm{~nm}$ after substitution of sulphur by nitrogen was observed. This indicates the importance of sulphur in metal chelation, and suggests that peak at $375 \mathrm{~nm}$ is due to the thiazole sulphur of ambilhar.

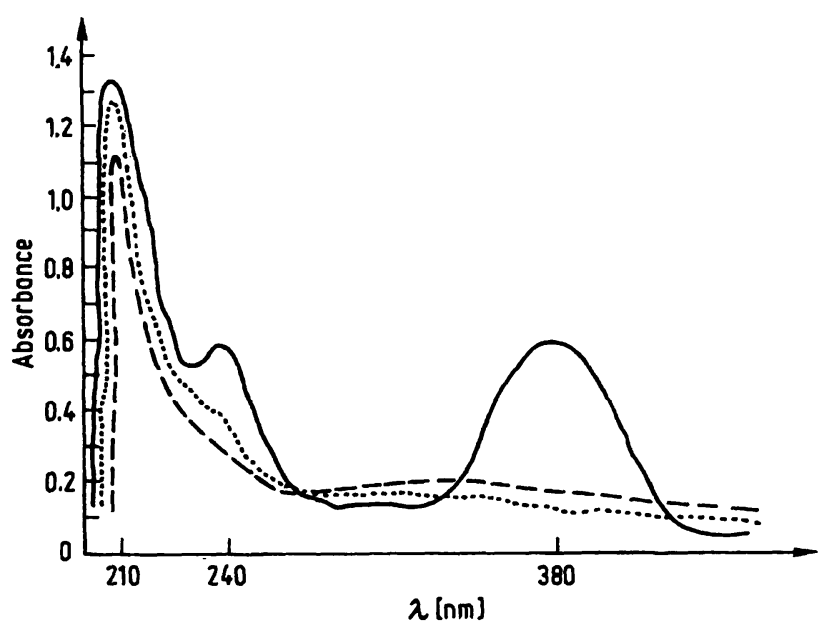

Fig. 2. Ultra violet spectra of ambilhar $(-)$ and its nitrogen analogue in the presence of iron $(\cdots \cdots)$ and in the absence of iron (-- ). Addition of iron did not produce any change in the spectrum of the nitrogen-substituted derivative. On the other hand substitution of sulphur by nitrogen resulted in disappearance of the peak at $375-380 \mathrm{~nm}$ in ambilhar.

\section{Discussion}

It is clear from table 1 that substitution of thiazolyl sulphur of ambilhar by nitrogen resulted in a significant decrease in the ability of the drug to increase urinary iron output. Such an observation could be important evidence for the role of thiazole sulphur in the chelation of iron and possibly other metals (5).

The ultra violet spectra of ambilhar and its nitrogen analogue suggest that the thiazole ring and more specifically its sulphur could be responsible for the major peak at $375 \mathrm{~nm}$ which disappeared after metal chelation or substitution by nitrogen (fig. 1, 2). Also, reduction of the drug is essential for chelation with iron in vitro, forming three different chelates. This is further supported by the findings of Feller et al. (8) and Morita et al. (9) that niridazole or ambilhar is reduced in vivo by liver microsomes and subsequently by rat liver xanthine oxidase.

In vitro, the drug formed three different chelates with iron. In our view the isolation of ambilhar iron chelates with lesser amounts of iron (complexes 2,3 ) is probably due to incomplete reaction in vitro.

However, in vivo, one atom of iron chelated with 6 molecules of the drug (4), which is probably due to the lower concentration of the metal in liver.

Finally the presence and wide distribution of iron sulphur complexes in animal and plant tissues support our view of the involvement of thiazolyl sulphur in the process of iron chelation $(10,11)$.

\section{References}

1. Lambert, C. R. (1964) Experientia 20, 452

2. Salah, M. K., Hammady, I. M., Hamed, M. Y. \& Abdel Aziz, F. T. (1970) Zbl. Vet. Med. A 17, 257-260.

3. Salah, M. K. \& Abdel Aziz, F. T. (1974) Zbl. Vet. Med. A 21, 344-347.

4. Abdel Aziz, F. T., Al-mallah, A. K. \& Hassanein, R. R. (1976) Zbl. Vet. Med. A 23, 475-478.

5. Al-Khayat, T. M. N., Abdel Aziz, F. T. \& Izzat, N. N. (1978) J. Clin. Chem. Clin. Biochem. 16, 11-13.

6. Ramsay, W. N. M. (1958) Advañces in clinical chemistry; vol. 1 p. 1 (Sobotka, H. \& Stewart, C. P., eds.) Academic Press, New York.

7. El-Kholy, I. F., Rafla, K. \& Soliman, G. (1961) J. Chem. Soc. 85, 4490-4498.

8. Feller, D. R., Morita, M. \& Gillette, J. R. (1971) Biochem. Pharmacol. 20, 203-215.

9. Morita, M., Feller, R. \& Gillette, J. R. (1971) Biochem. Pharmacol. 20, 217-226.

10. Lehninger, A. L. (1975) Biochemistry. 2nd. Ed. Publ. Worth. I. N. C. New York. p. 488-489.

11. Sweeney, W. V. \& Rabinowitz, J. C. (1980) Ann. Rev. Biochem. 49, 139-161.

F. T. Abdel Aziz Prof. of Biochemistry Medical College Mosul University Mosul Iraq 
